\title{
Celebrating Slang and Unconventional English, Once Again: An Interview with Terry Victor
}

\author{
Antonio Lillo \\ University of Alicante \\ antonio.lillo@ua.es
}

Much water has flowed under the bridge of lexicography since Quirk (1980:24) noted that Eric Partridge's masterwork A Dictionary of Slang and Unconventional English (also known as the $D S U E$ ) was likely to be the best slang dictionary we could expect to have for many years to come. But time has shown that he made no exaggeration in his praise. Using Farmer and Henley's monumental Slang and Its Analogues (1890-1904) as a basis on which to build his own work, Partridge managed to provide in his dictionary the most comprehensive and authoritative picture of English slang ever. Or rather a succession of snapshots, for in a span of nearly fifty years, from its first publication in 1937 up to 1984, it went through eight editions, the last being revised and updated by Paul Beale after the author's death in 1979. Given his sound literary background and his romantic outlook on philology - Partridge was a philologist in the strictest etymological sense, a true lover of words - he was remarkably well qualified for collecting slang words and dissecting their meaning and history. And this he did so brilliantly, so devotedly, that even today, when a large number of technological resources have greatly eased dictionary making, one cannot help being awed by the sheer depth and breadth of his work. Weaknesses it has (what dictionary does not?), one of them being its patchy coverage of American slang, another - and arguably the most serious - its wild guesses at the etymology of many a word. Yet the overall achievement far outweighs such flaws. Partridge's huge strengths in recording British military and underworld slang, especially up until the mid-20th century, are undeniable, and so is the merit of setting right the mistakes of others who, before him, had ventured into the murky depths of slang etymology. 
As the truism goes, however, no dictionary travels well through time. And this, of course, holds even truer for a slang dictionary that has not been updated since the mid1980s. Now, over two decades after the publication of its eighth edition, the spirit of the DSUE has been captured in The New Partridge Dictionary of Slang and Unconventional English (due out in November 2005), an all-encompassing, two-volume record of the slang used throughout the English-speaking world from World War II down to the present day. With a view to offering a balanced coverage of the two largest varieties of English, British and American, Routledge has entrusted the continuation of the Partridge tradition to two editors, one based in the UK, the other in the US. The UK portion of the dictionary has been entirely the responsibility of Terry Victor, an accomplished actor, writer and director with a lifelong passion for slang and verbal wit of all kinds, from the ribald to the sublime. The US register has been compiled by no less than the American slang-meister Tom Dalzell, author of Flappers 2 Rappers (1996) and The Slang of Sin (1998).

What follows is an interview I conducted with Terry Victor in March 2005 at my home in Santa Pola, just a few miles from where he and his wife were taking a short holiday. Although he was having a much-needed break from work, he readily accepted my invitation to come and talk about all matters slang. Among many other things, we talked about the making of The New Partridge and the extraordinary adventure of rewriting its classic forebear for the 21st century. A slang man through and through, Terry's wealth of knowledge and ebullient personality shone through the whole conversation, and will no doubt enliven many of the entries he has written for the dictionary.

ANTONIO LILLO: To begin at the beginning, how did you first get into slang lexicography?

TERRY VICTOR: I've long had a fascination with slang and a passion for dictionaries and, within that passion, Eric Partridge has always been one of my heroes. When I met Liz, my wife - she also has a passion for books, which is just as well -, we got into the habit of going to book fairs, and slowly my dictionary collection got bigger and bigger. It was actually through that collection of dictionaries that I got to meet Tom Dalzell. A book dealer from Edinburgh told me of someone she said I should meet in San Francisco. We were on holiday in San Francisco, and Tom and I arranged to meet in a bookshop called Serendipity, which is one of the nicest cosmic jokes I can think of. Then it really got kind of strange, because I'm a vegetarian, Tom is a vegetarian - and he lives in the meat-eating centre of the world -, he has a son called Jake, we have a grandson called Jake, I'm very much involved in the actor's union Equity and Tom is an American attorney who works for a union. Besides our love for slang, we found we had lots of things in common, and we stayed in touch for quite some time, swapping books and all that sort of thing.

Time moved on and, when Routledge decided to resurrect the Partridge brand, they scoured around and found Tom, who had already published Flappers 2 Rappers and The Slang of Sin. He was also asked to recommend a couple of people. Although Tom and I hadn't actually been in touch for a year or so, I was on the list, so they got in 
touch, he got in touch and, well, the whole actor's mentality clicks in there: if someone asks you if you can do a certain thing, you say yes and then go and learn how to do it. My mentality is that once I say yes, I commit. Routledge wanted me to write a glossary to prove that I could do this. Of course, I had read many glossaries, but I'd never ever done one. I got down to it and did a milkshake glossary that linked banana to vanilla, just for the sake of having a route. In retrospect, I can see that it was a terribly flawed piece of work, yet fortunately the people who read it somehow understood that it was my first attempt. Michael Quinion, who is a very respected language writer, read it and said 'Go! This is good work' - words to that effect, anyway - and, well, that's how it all started. Then Eric Partridge's daughter approved the line-up of Tom and I, and we started to try and work out what was what.

AL: The beginning is always the hardest. Did you find it difficult to decide on the sort of dictionary you were to compile?

TV: Well, Tom has an idea of what a dictionary should be because he's written two good glossaries, but I had no idea at all. I only know what I enjoy in a dictionary. In order to get familiar with the intricacies and technical aspects of dictionary making, we had the help of a consultant lexicographer, John Williams from Liverpool, and we started reading and collecting, but I really didn't have a clue when the contract started. In fact, it was not until February 2001 that we really got started. To be honest, even after all this time, I still can't see the dictionary in my head; I can just see the entries, and especially the spirit.

AL: So what exactly was your philosophy in writing this dictionary?

TV: Our philosophy was to capture the spirit of Partridge. He was great till 1945, but you get past there and his weaknesses begin to show: he's not good on contemporary 1950s or 1960s and certainly not good on drugs or counterculture. He'd also painted himself into a corner when he did the first edition in 1937 and excluded American slang, though you know from the Dictionary of the Underworld [1st edn, 1949] that he was really desperate to include America. It was therefore pretty clear to us that this book needed a re-definition in and of itself. At first, this was to be the ninth edition of Partridge's work, but we looked at the DSUE9 and it didn't make sense. We were actually doing a new book. We then had an arrangement with the Partridge estate to use a portion of the existing work, and I got the shorter end of the stick on that one. I was the one who worked all the way through, cross-checking back to all the previous editions and deciding where to cut. In a way, our dictionary could well be regarded as a companion volume to the eighth edition.

AL: That edition was published way back in 1984. As much slang is short-lived, The New Partridge must differ from it in many ways. Leaving aside the fact that, unlike 
Partridge, you've included a vast amount of American terms, what are the main similarities and differences between your dictionary and Partridge's?

TV: As I said, the similarity is in the spirit. We've always enjoyed and loved the work of Eric Partridge. Basically, we've tried to capture the spirit and the scholarship and take that into this new collection of words. Maybe up to ten per cent - probably a lot less - are taken from the DSUE8 into The New Partridge, but very early on we realized it couldn't be a ninth edition. The revisions are too huge. This is a new book on the principles of Eric Partridge; actually, more than just the principles, because he guessed, whereas if we don't know, we say we don't know or we leave it alone. If you've got nothing to add, quite often it's worth adding nothing.

Another important difference lies in the classification of slang. Partridge's register was very confusing and his labelling system was very rigid, with categories such as 'cant', 'low' and 'public school'. Slang, certainly in our lifetimes, doesn't stay in its corner. Though it may for a while, it soon spreads into the wider world. For instance, we all know some prison slang; we all know words like snout and nonce. Once upon a time this was a private slang vocabulary and you could have used 'cant' for the underworld slang, but nowadays, thanks to mass communication, you can't do it. I should say that, despite the huge differences between Partridge's dictionary and ours, the heart is really the same.

AL: From what you're saying, I take it that those differences must be easily noticeable in most of the information you've included in each entry. Can you tell me a bit about that? What kind of information have you put in the entries?

TV: Firstly, we've put the word; then a serious and totally untainted definition. You'll notice differences, for instance, where it comes to sex. We haven't gone biological about it; we just say 'to have sex' for any number of words with that definition, but Partridge has 'to coit' because in 1937, when he first published the dictionary, that was being very brave. We've made it 'to have sex', which is more informal and more discursive. Then we have a gloss, which gives information about the word. In the glosses, Partridge was often the man who would let you know his point of view, not in as many words, but you could easily understand what was being said in his glosses. In our glosses, you can also see that, like Partridge, we're not afraid of wearing our hearts on our sleeves.

AL: That means you also give plenty of social and cultural information in the entries?

TV: Well, very often it's just a piece of local colour or a bit of something amusing. A good example in point is gotcha. Green [1998] in fact gives the locus classicus as the headline in the Sun, but because of the format of his dictionary he can't say why it is the locus classicus. We have room to say that the Belgrano was sailing away from the 
Falklands when Mrs Thatcher ordered the attack. The headline the next day was 'Gotcha!', and all this information gives a whole sense of meaning to the word. Without the gloss, the depth is lost.

AL: In this kind of dictionary there are many words that might be considered racist or offensive. Have you labelled them in some way?

TV: In the case of racist words, we warn you most of the time, though not always. For example, Taffy and Jock are not particularly racist. They may only be considered racist in the loosest terms. When you get to the more dangerous words like nigger or spic, then we do say that they are derogatory or offensive; mind you, we label them within the glossary. We haven't actually badged words, because sometimes it really isn't worth it. Would you, for instance, badge queer as an offensive word?

AL: Certainly not, though it may be hostile in certain contexts.

TV: Exactly. What we've had to do is gloss that kind of information, because you can't just say it's offensive, and that gloss gives it a lot of life. Partridge, bless him, although he did not always like what he was writing about, never excluded. He was allembracing, and that is what this book is.

AL: You said earlier that you've also kept some of the entries of the original Partridge. How have you managed to revise these entries without destroying the style and essence of Partridge?

TV: To be honest, we haven't used - as far as possible, unless we're citing from another work - a single word of Partridge. We've used all sorts of formulae to rephrase or to make the definitions sound more modern. I'm going back to have sex as an equivalent of to coit. We've changed the wording of the definition, but not the sense, unless our information on the word has advanced. After all, a dictionary is a snapshot in time. In some cases, we do know more, and so, with hindsight, Partridge was obviously misinformed, but, in context, he was probably very accurate or just making a very clever guess.

AL: Probably the most basic problem a slang lexicographer has to face is that of determining what is slang - or unconventional English - and what is not. The big question is, how have you gone about deciding what to include in the dictionary?

TV: We were tempted for a while to include words like pram and bus because they were originally slang. Still, as these words have long been part of standard English, we thought that would have been too pedantic. We finally settled that slang is an informal register where the word imparts as much by its use as the sense of the word. A slang 
term, therefore, always carries two meanings: it carries the meaning in itself and its cultural meaning. Of course, in the dictionary you'll find the odd jargon word and the odd colloquialism, because they're fascinating or they're sitting next to another word that has a relevance too. There is no definition of slang at the end of the day, but in the main we've ruled that it needs to say something about the society it keeps.

AL: Beyond that, in order to label a word as slang you need to take into account the attitude of the speaker. It's also often the case that the pronunciation makes the word itself slang, as when the word bad is pronounced with a long drawn-out vowel ...

TV: Indeed, yes. For instance, a phrase like Have a nice day! is not slang, but it is slang when you say it ironically; Tom, who has put that entry in, has also had to describe the intonation that goes with it. And then there are other words that go beyond, like sharking, which is when young men and women go out pursuing members of the opposite sex. The first time I heard it I didn't even hear the word. I was talking to a woman and said 'What are you doing tonight?' She just put two hands on top of her head and made a shark's fin. That was it. The definition of the word sharking should, of course, include all this information.

The V-sign gets used as spoken slang as well in the phrase flipping the $V$. So you have to define what a V-sign is. Obviously, sometimes it's impossible to put all these things in alphabetical order in the dictionary. One of those things that we had to put in the introductory matter because we couldn't define it is [silence].

\section{AL: What do you mean?}

TV: That was it! When you say 'what the -.--'s going on?', that silence is probably the word fuck, but how do you put that in the dictionary? However, that sort of non-verbal language is also slang or unconventional English, not because the word itself is left out, but because the information is 'we can't use this word in this place'. The silence doesn't have its place in the dictionary, so we've put it in the introductory matter. In the introduction we've actually put in some references to some very arcane areas. We've not put much in the way of emoticons, though, but they're slang.

AL: So are most of the acronyms used in texting, aren't they?

TV: Absolutely. Texting is a vocabulary we've touched upon but without working through because, to be honest, we haven't got enough pages for all the words. Another area we've included is warchalking, the practice of finding wireless networks for your Internet connection and then putting the signs down with chalk. I had to get the database people to actually make the characters, because the definition was absolutely pointless without them. Most of them are probably out of date now, though. 
AL: Well, as you said, the dictionary is a snapshot in time. For that very reason, despite the wide coverage of the dictionary, you must have left out many historical usages. How did you do that?

TV: Bloody-mindedly, we made our minds up. If you knew a word was still current, you'd include it. If a word was possibly dead but was important, you'd also include it. If it was possibly important and probably dead, then it hovered on the edge.

AL: I guess the number of citations you have in your database also helped you decide what and what not to include?

TV: That's right. For some words we've got huge quantities of citations, particularly when you get to things like joint and screw, you know, the big slang words in America. There are any number of sources for these words, but they're all literary, sound sources, and it's really hard to say 'We're going to keep Kerouac, but cut Ginsberg'. I work from the other end: because the UK register was already there, I've gone to the modern words, and even if we had an early usage for the word, I've tended to include the fairly current usage, since the words were already well attested to in 1984 . Other words have come up since 1984 and, obviously, they've got to go in, otherwise we'd be writing an irrelevant dictionary. So we're finding a way to make it the most relevant, enjoyable dictionary. Possibly, the American slang will have the extra weight on a historical basis, simply because it wasn't in there in the old Partridge. As far as contemporary slang goes, possibly the UK has a more detailed coverage, as I've been able to concentrate more on that.

AL: We all know that, because of its casual nature, slang occurs much more frequently in the spoken language than in the written. How have you coped with the oral material? Have you gathered oral citations?

TV: Oh, yes, but not hugely. They've been collected for the most part by chance and we've kept the sources anonymous. We've identified them with labels such as 'A schoolgirl overheard in Gloucester' or 'In August 2001 a schoolgirl in Gloucester said ...'. If the word then dies, then we can lose the word. If it lives, there is an earlier citation for other people to work on from.

Basically, everyone I've met in the last five years has contributed something to the dictionary. For instance, my wife's boss: we had him to dinner one day and, as he's a caver, we got him to come up with a caving glossary. Most of that is checkable, but a couple of uncheckable words were so good they were in. I know I've also got some words from a retailer. Some time ago I was talking to the guy in an electrical store and said 'What do you call customers that waste your time?' 'Tyre-kickers,' he said. Interestingly, I found that the word tyre-kicker, which comes from the slang of the motor trade, has made its way into the slang of the wider retail trade. 
$\mathrm{AL}$ : That raises an interesting point, because many lexicographers look at oral attestations with suspicion, especially when they're not checkable. Have you checked whether the material you have gathered from oral sources is really genuine?

TV: Yes, we have cross-checked it using other sources, especially dictionaries and glossaries, but, of course, there are always some words which you can't find elsewhere.

AL: Meaning that you've done your own fieldwork?

TV: Precisely.

AL: What about the oral material from the DSUE8? Partridge himself relied heavily on readers and correspondents to supply new words and citations, but it's never been clear to me whether he somehow checked their authenticity.

TV: We've cut a lot of the oral material; also, Beale did the same. Albert Petch and one or two others show up an awful lot with Partridge. Maybe the words they contributed were on the streets in the first half of the 20th century, but they haven't survived and we haven't been able to prove their existence in any other way. In those cases, most of the references have gone. If we have a sense that they're still around - and sometimes you just have to go with that gut feeling - we've kept them; in the main, however, we've let them go because there are too many other words.

AL: One of the most common criticisms of Partridge is his tendency to guesstimate when words first appeared. Have you revised his datings of words?

TV: Wherever there's proof, yes, and in most cases where we've not been certain we've just bypassed that piece of Partridge. Sometimes you can be certain or the likelihood is he was right, but instead of dating a word as '18th century', we say 'probably 18th century' or 'there is some evidence that it was around in the 17th century, but it doesn't appear in writing until the 18th'. We gloss the information and we've not, as far as possible, taken a hard opinion because we don't want to look like idiots.

AL: Have you also looked for citations that illustrate the first use of words, including those you have kept from the DSUE8?

TV: Yes, where possible, but we haven't gone out of our way to find antedatings because in the time scale that was allowed we both had to stick to likelihoods. When the second edition comes along, hopefully we'll be able to improve many entries and antedate many words. 
AL: The coverage of The New Partridge is not confined to British and American slang. It also includes a fair amount of slang from other English-speaking countries, like Australia, Ireland, South Africa and the Caribbean. How have you collected that material?

TV: Some by contributors, some by research. The same as Partridge used Sidney Baker a lot for Australia, Tom found John Lambert, who did a huge body of work for us on Australian slang. We also have a Caribbean, a New Zealand, a Canadian and an Irish contributor who have supplied a lot of words. Beyond that, it's been mainly research. I did South Africa by combing through several dictionaries, then combing through files of the South African Sunday Times and reading books, and then finally, very luckily but too late now, I've discovered that YFM has published a CD dictionary of Scamto, the street slang of South Africa's urban youth. We've got there by dint of perseverance, and, if there's a shortfall in one area, we kind of hope that when people read the book they'll get in touch and draw our attention to it so that we can improve the material for the second edition. In this way, we hope the dictionary will be a growing thing.

If you look at the differences between the 1937 first Partridge and its later editions, you'll see he added little bits all the way through till the fifth or the sixth. Then there's a whole supplement on the sixth, half as big again as the book, and by the time he got to the eighth, it was two volumes. Mainly when you look at the front of Partridge it's him saying thank you to all the people who sent him words. We're saying thank you to a lot of them as well because we've built on their work.

$\mathrm{AL}$ : The main focus of the dictionary is the slang used during the period from World War II onwards. Do you think this has been a particularly creative and prolific era for slang creation?

TV: [Takes a deep breath and says:] The beat culture, counterculture, rock ' $n$ ' roll, the Beatles, the mods, hip-hop, Eminem ... Eminem is a rhyming storyteller on a par with Shakespeare, no question. He's an absolute master, and he uses new words and makes up words, just like Shakespeare: if he couldn't get a rhyme, he'd make the word up. By and large, however, I don't think that any time is better or worse than any time for language, with one big exception: the Puritan period in English history. Slang celebrates the underclasses, it is our language, but Puritanism takes away our vocabulary, and that disempowers so badly every single one of us ... That really frightens me.

In a bigger picture, I hope the dictionary is one of the bastions against Puritanism. I think the biggest bastion is the Internet, yet one of these days they'll control that, and at that point ... well, control is power. I'm afraid we've had little language Talibans popping up here and there currently, and this book should prove why it's not necessary, because we can run the world without any kind of censorship or control over our language. 
AL: Which brings me to a point that some readers might be wondering about. Every dictionary - slang and otherwise - paints a social and cultural portrait of the speakers that use a language. We can see, with only a cursory glance at any good dictionary of American slang, that the black community is the one that has contributed the most to slang in the US. What social groups have been most influential in the development of slang in the UK for the past few decades?

TV: Jamaican, West Indian. That's the main growth area. Take reggae as a simple form, that travelled worldwide, that began to affect people's vocabularies. The Jamaicans and the West Indians travelled worldwide. Certainly, since the mid-50s there's been a very large black population in the UK who have slowly assimilated without losing their own patois, and that patois, through music and youth, has influenced everybody's language to a degree.

I met someone in Bristol who told me he'd heard two white kids calling each other nigger - this was in the most black area of Bristol - because they'd heard the black kids calling each other that word. That means that nigger has been decriminalised in English. Suddenly the word doesn't mean 'black'; it means 'friend', which clearly shows the extent to which black English is having an influence on mainstream British slang.

AL: Speaking of social and cultural things - and this is just a point of curiosity -, do you think there might be a cultural explanation for the proliferation in the UK of words for certain taboo concepts which are hardly represented in other languages? The concept of haemorrhoids, for instance, has spawned a pretty good bunch of words, like Chalfonts, farmers, Emma Freuds and bum grapes. Do you have an explanation for that?

TV: It's got to do with natural national obsessions. I think the UK is pretty much recognised as a very repressed sexual society, and haemorrhoids are an area where you have to acknowledge it, but it's still below the waist, so people find euphemistic ways to talk about it. No doubt, our main national obsession is sex, and that comes out as much in what we say, in our slang vocabulary, as in what we leave out. Curiously enough, the earliest dirty joke in English dates back to the 10th century. It's a riddle, and the short version is 'What's long and hard, and hangs by a man's thigh and sometimes goes into a hole?'

AL: I can't figure out what the answer is.

TV: A key! Well, probably ... You see? We've been like it for a thousand years. We're the masters of innuendo, since we've always been a bit repressed and, culturally, we've learned to do dirty jokes without making them dirty. This is something we do all the 
time. Take for instance the joke that got Max Miller banned from the BBC: 'I was walking along the mountain path, walking along the mountain path, a sheer drop one way and a sheer mountain the other way, a sheer drop one way and a sheer mountain the other way. There was a naked blonde walking towards me. Well, I didn't know whether to toss meself off or block her passage'. He said nothing wrong! That's what we've always done, because it's part of the English culture.

AL: Aside from this fondness you have for verbal wit, which I'm sure must be written into many entries of your dictionary, do you have a favourite slang word and etymology?

TV: My favourite word is actually quite old, since it was collected by Francis Grose: nincompoop. That's what my mother used to call me when I was a kid. She went 'Don't be an idiot. Don't be such a nincompoop'. Grose [1785: s.v. nickumpoop, or nincumpoop] defines it as a man who has never seen his wife's private parts. That definition is perfect, and I've included that particular word in the dictionary because it reminds me of my childhood and makes me smile.

As for etymology, I would say my favourite word is Jim Jones, which is used to denote marijuana laced with cocaine and PCP (angel dust). The message behind this word is that not only does it give you the high, the dream, it also gives you the pain. Jim Jones was a preacher who led a religious group down to Guyana to set up Jonestown, a religious community, and when the dream went sour he got them to commit mass suicide by drinking cyanide-spiked Kool-Aid. It was so sad when all these people with dreams and aspirations were murdered - or self-murdered - and this one word, Jim Jones, came to be used by drug-takers, the message being 'there's the dream and there's the death, all in the same bit of drugs'. I think this is a word of great importance because it demonstrates very clearly how subtle some slang can be.

AL: That's a flash of demotic poetry, that is. Now finally, what's next? Do you have any slang books or dictionaries in the pipeline?

TV: Oh, yes, we've got several already marked out - isn't that nice to say! - and contracts signed. The next one is to be the American, which is Tom's responsibility particularly, and then there's the concise version of the big one, which will have some 750 pages. There are also two or three others in the pipeline, but I don't want to say what they are because you'll be so delighted when you see them. The essence with any dictionary is that once you've got the database, the database should continue to grow. We've spent five years building a database, we'll continue to build it and, with luck, we'll still be there for the second or maybe the third edition. Who knows, our lives may change entirely, and it may have an impact, good or bad, on my acting. I have no huge pretensions about this dictionary, though. It's just a book I want to read. That's the best thing I can say about it. 


\section{Works Cited}

Dalzell, Tom (1996): Flappers 2 Rappers. Springfield, Mass.: Merriam-Webster. . (1998): The Slang of Sin. Springfield, Mass.: Merriam-Webster.

Farmer, John S. and W.E. Henley (1890-1904): Slang and Its Analogues Past and Present. 7 vols. London and Edinburgh: Published for subscribers only.

Green, Jonathon (1998): The Cassell Dictionary of Slang. London: Cassell.

Grose, Captain Francis (1785): A Classical Dictionary of the Vulgar Tongue. London: S. Hooper.

Partridge, Eric (1937-84): A Dictionary of Slang and Unconventional English. London: Routledge. (1st edn 1937; Supplement, 1938; 2nd edn, 1938; 3rd edn, 1949; 4th edn, 1951; 5th edn, 2 vols., 1961; 6th edn, 2 vols., 1967; 7th edn, 2 vols., 1970; 8th edn, 1 vol., 1984, ed. by Paul Beale.) . (1949): A Dictionary of the Underworld, British and American. New York: Bonanza Books.

Quirk, Randolph (1980): “An Adjunct to Ourself”. In David Crystal, ed., Eric Partridge in His Own Words. London: André Deutsch, 19-25. 